\title{
Squamous Cell Carcinoma of The Tongue in A Developing Community
}

\author{
Wilson I B Onuigbo* \\ Department of Pathology, Medical Foundation and Clinic, Nigeria
}

Submission: December 18, 2018; Published: January 09, 2019

*Corresponding author: Wilson IB Onuigbo, Department of Pathology, Medical Foundation and Clinic, 8, Nsukka Lane, Enugu 400001, Nigeria

\begin{abstract}
Squamous cell carcinoma of the tongue is characterized by malignant cells which show squamous differentiation in the direction of "formation of keratin and/or the presence of intercellular bridges." As single case reports have appeared in the literature recently, this paper presents a good number of them traced among the Ibo ethnic group in Nigeria, this being facilitated by the author who heads an institution that provides a histopathology data pool.
\end{abstract}

Keywords: Tongue; Malignancy; Squamous cell carcinoma; Epidemiology; Developing community

\section{Introduction}

Squamous cell carcinoma is defined as "a malignant epithelial neoplasm exhibiting squamous differentiation as characterized by the formation of keratin and/or the presence of intercellular bridges" [1]. This was illustrated in a case report from India [1] as well as from Saudi Arabia [2] and from the UK [3]. Therefore, this paper presents a series from the Ibo ethnic group's developing community [4], this being done on account of the author's headship of a histopathology data pool such as the one fostered by a Birmingham (UK) group [5]. To facilitate matters, the tabular form is used as shown hereunder.

Results

Table 1

Table 1: Epidemiological distribution by age.

\begin{tabular}{|c|c|c|c|}
\hline Age range & Male & Female & Total \\
\hline$<40$ & 1 & 1 & 2 \\
\hline $41-50$ & 2 & 2 & 4 \\
\hline $51-60$ & 1 & 2 & 3 \\
\hline $61-70$ & 3 & 2 & 5 \\
\hline $71+$ & 1 & - & 1 \\
\hline Total & 8 & 7 & 15 \\
\hline
\end{tabular}

Table 2: Site of involvement.

\begin{tabular}{|c|c|}
\hline Site & No \\
\hline Side & 5 \\
\hline Posterior $1 / 3$ & 4 \\
\hline Dorsum & 2 \\
\hline Base & 1 \\
\hline
\end{tabular}

\begin{tabular}{|c|c|}
\hline Half & 1 \\
\hline Not stated & 2 \\
\hline Total & 15 \\
\hline
\end{tabular}

Table 2

In contrast, only few of the published cases designated the sites, including

1) Side

2) Lateral border

3) Margin.

\section{Discussion}

Wide interest in squamous cell carcinomas of the tongue is shown in the publications which have appeared recently in countries as far apart as China [6], France [7], UK [8] and USA $[9,10]$. Therefore, the local cohort ought to be compared with them. In this context, the mean age was given as 60 years from India [1]. Age stands out. The Chinese group was aged 28 to 88 years, but the mean age was not apparent [6]. The local cohort was aged 34 years to 79 years (mean 56 years). As to sex, the local cohort was almost equal. It was disparate in China to the tune of 102 males to 83 females [6]. What stood out was a rare histological variant. It was reported from Spain [11]. It turned out to be the infrequent and aggressive "spindle cell type" that featured in a 11-year-old boy.

\section{References}

1. Vaidya S, Kapoor C, Ohri N (2013) Early invasive squamous cell carcinoma of the tongue. SRM J Res Dent Sci 4: 35-38. 
2. Algowaifly M, Alhadlaq RK (2016) Oral squamous cell carcinoma on the lateral border of the tongue: A case report. Dentistry 6: 381.

3. Rui PP, Albuquerque DDS, Richards A (2016) Squamous-cell carcinoma of the tongue. N Engl J Med 374: e32.

4. Basden GT, Celestine, Chukwuemeka, Mbaegbu (1996) The Effective Power of Music in Africa. Niger Ibos London: Frank Cass.

5. Macartney JC, Rollaston TP, Codling BW (1980) Use of a histopathology data pool for epidemiological analysis. J Clin Pathol 33(4): 351-353.

6. Lin GC, Qiu WL, Zhang ZY (2003) Relevant factors and management for patients with squamous carcinoma in tongue without clinical cervical lymphatic node metastasis. Zhonghua Kou Qiang Yi Xue Za Zhi 38(1): 5-8.

7. Zwetyenga N, Majoufre Lefebvre C, Siberchicot F (2003) Squamouscell carcinoma of the tongue: Treatment results and prognosis. Rev Stomatol Chir Maxillofac 104(1): 10-17.
8. Jones AS, Rafferty M, Fenton JE (2007) Treatment of squamous cell carcinoma of the tongue base: Irradiation, surgery, or palliation? Ann Otol Rhinol Laryngol 116(2): 92-99.

9. Ganly I, Patel S, Shah J (2012) Early stage squamous cell carcinoma of the oral tongue Clinicopathologic features affected outcome. Cancer 118(1): 101-111.

10. Gourin CG, Johnson JT (2001) Surgical treatment of squamous cell carcinoma of the base of tongue. Head Neck 23(8): 653-660.

11. Ruiz Martin I, Garcia Recuero I, Urbanowicz M, Zubillaga Rodriguez I (2016) Spindle cell squamous carcinoma of the tongue in a child. Oral Maxillofac Surg Cases 2(4): 40-45.

\section{Your next submission with Juniper Publishers will reach you the below assets}

- Quality Editorial service

- Swift Peer Review

- Reprints availability

- E-prints Service

- Manuscript Podcast for convenient understanding

- Global attainment for your research

- Manuscript accessibility in different formats ( Pdf, E-pub, Full Text, Audio)

- Unceasing customer service

Track the below URL for one-step submission https://juniperpublishers.com/online-submission.php 